\title{
What do historians really think about biography?
}

\author{
O que os historiadores realmente pensam sobre a biografia?
}

Adrian Shubert

York University, Toronto, Ontario, Canada

$\diamond$

\begin{abstract}
This article explores the ways in which historians have thought about biography as a genre of writing about the past and how these attitudes have changed over the last fifty years or so, from skepticism and even hostility to increasing acceptance and even advocacy. It also examines some of the ways in which biography itself has evolved and the contribution of historians to this evolution, before concluding with an example from the author's forthcoming biography of the $19^{\text {th }}$-century Spanish military and political figure Baldomero Espartero (1793-1879).
\end{abstract}

Keywords: Biography; Historiography; Espartero

Resumo: Este artigo examinava as varias caminhas que os historiadores pensava sobre o válor do gênero da biografia nas considerações do nosso passado, e a mudança nas manieras de ver biografia entre nos ultimos cinquentos anos: atitudes alterava de cetecismo e oposição ao aceitação, confiança, e promoçåo da biografia a un gênero respeitável da História. Tambem, o artigo considerava o evolução da biografia e o contribução dos Historiadores ao aquele evolução. Finalemente, o artigo vai concluir com un exemplo da biografia - que vai publicar sobre Baldomero Espartero (1793-1879) - escrevendo do mesmo autor deste artigo.

Palavras-chave: Biografia; Historiografia; Espartero

Let me begin these reflections on history and biography with some autobiography. I began my undergraduate degree in History in 1971 and received my $\mathrm{PhD}$ in 1981 but have I made my first foray into biography only very recently. I came of age as a historian in the 1970s much influenced by E.P. Thompson's approach to social history so well summarized in the preface to his Making of the English Working Class. "I am seeking to rescue the poor stockinger, the Luddite cropper, the 'obsolete' hand-loom weaver, the 'utopian' artisan, and even the deluded follower of Joanna Southcott, from the enormous condescension of posterity". ${ }^{1}$ I wrote my doctoral thesis on the social history of a crucial part of the Spanish working class, the coal miners of Asturias, and continued to write social history in my next two books, one a survey of the social history of modern Spain, the other a social and economic history of bullfighting. ${ }^{2}$ Then, with a friend, I wrote a textbook for the new final year

\footnotetext{
1 E. P. Thompson, The Making of the English Working Class. London: Victor Gollancz, 1963.

2 Hacia la revolución: orígenes sociales del movimiento obrero en Asturias, 1860-1934 (Barcelona, 1984); Historia social de España (1800-1990) (Madrid, 2000); A las cinco de la tarde: una historia social del toreo (Madrid, 2002).
}

history course in Ontario high schools, world history since $1500 .^{3}$ Only in 2010 did I take the plunge into writing a biography, although I had been toying with it for a long time. That project, a biography of the $19^{\text {th }}$-century Spanish military and political figure Baldomero Espartero (1793-1879) is now finished and will be published in the autumn of $2018 .{ }^{4}$ During these last few years I read more biographies than I had previously. I also read about biography as a form of writing about the past and this is the context in which my thoughts on the relationship between historians and biography have developed. What stands out above all is the widespread skepticism, even outright rejection, for the genre among professional historians. Biography and history are not quite "two solitudes", to borrow the evocative title of a famous Canadian novel, ${ }^{5}$ but they are two worlds whose points of intersection have been fewer than one might anticipate.

$$
* * *
$$

\footnotetext{
3 Arthur Haberman and Adrian Shubert, The West and the World: Contacts, Conflicts, Connections (Toronto, 2002).

4 Adrian Shubert, El Pacificador. Baldomero Espartero y la formación de la España contemporánea (Barcelona, 2018)

5 Hugh MacLennan, Two Solitudes (Toronto, 1945)
} 
In the English-speaking world at least, biography is one of the most popular forms of writing about the past. While we are not unique in this, I think we can highlight, to paraphrase E.P. Thompson, what we might call "the peculiarities of the English speakers." ${ }^{\text {"B }}$ Biography does seem to have a special purchase in the Anglosphere. This infatuation goes beyond the printed word: from 1999 to 2013 there was a "Biography" channel on cable television in the United States. Many places in the Anglosphere have dedicated prizes for biographical writing. Australia has had a National Biography Prize since 1996. The United States and the United Kingdom both have two prizes for the genre: the Pulitzer Prize for biography and autobiography and the PEN/Jacqueline Bograd Weld Award for Biography in the former and the Costa Book Awards and the Elizabeth Longford Prize in the latter. The taste for and practice of biography seem especially well developed in the UK. In recent review of Rudiger Safranski's biography of Goethe in NY Times Michael Hoffmann commented that: "In many instances, the Germans have been content for the lives of their great literary figures to be written by Anglo-American biographers; there is a narrative flair, a curiosity, an animation, a love of character and anecdote, a juice, that it seems only the English provide. Biography may be the true vice anglais". ${ }^{7}$ My own country, Canada, is a contrarian in this regard. In 2006, the Drainie-Taylor Biography Prize was discontinued and folded into the broader Writers' Trust Prize for Nonfiction. As if to compensate, the largest national chain of bookstores has separate sections for "History" and "Biography".

Despite this undeniable popularity, however, the relationship between historians and biography, even in the places where the genre is most popular, has been ambivalent, at best, frequently hostile and reaching at times, an almost visceral rejection. This goes back a very long way. Even Thucydides, considered the first historian in the western tradition, dismissed biography. It became more general in the $19^{\text {th }}$ century with the professionalization of history and then in the $20^{\text {th }}$ with the spread of Marxist historiography, the Annales, quantitative history and social history.

Through most of the past century, historians in France were particularly hostile. Biography was the classic form of the "histoire événementielle", the dust that settled on the surface, that Fernand Braudel sought to displace. ${ }^{8}$ Criticism became particularly sharp in the 1960 s and 1970s. Enchanted by the possibilities of quantitative

\footnotetext{
6 E. P. Thompson, "The Peculiarities of the English", in The Socialist Register, 1965, p. 311-362.

7 New York Times, 16 June, 2017, <https://www.nytimes.com/2017/06/16/ books/review/goethe-biography-rudiger-safranski.html>.

8 Fernand Braudel, "Histoire et Sciences Sociales: La longue durée", in Réseaux. Communication - Technologie - Société, 1987, v. 27, p. 7-37. The phrase itself was coined by Francois Simiand.
}

methods, Emmanuel Leroy Ladurie sought a "history without people". ${ }^{9}$ Jacques LeGoff sought to discover mentalités, ways of understanding the world that were collective and transcended individuals, what he described as "the daily and the automatic... that which escapes the subjects of history, that which Columbus shared with the least of his crew."10 In the crucial year of 1989, which saw both the bicentenary of the French Revolution and the fall of the Berlin Wall, Marc Ferro spoke of "cette handicapée de l'histoire". ${ }^{11}$ Most influentially of all, Pierre Bourdieu denounced what, in a short essay, he called "The Biographical Illusion". ${ }^{12}$

English-speaking historians could be equally scathing, expressing themselves in terms that make Henry James' description of a biographer in the Aspern Papers as a "publishing scoundrel" seem mild. ${ }^{13}$ As in France, the 1960s and 1970s were crucial. Social history was the growth field in those years. Its practitioners concerned with social groups and the unknown individuals who left few traces in the historical records whereas the dominant, if not only, subjects of biography were members of the elite. They were also struggling for professional space against political and diplomatic history, the privileged fields of biography. ${ }^{14}$ But the suspicion of biography was not the monopoly of progressives. Even so conservative a figure as British historian Geoffrey Elton denounced it. He was prepared to countenance biography as an acceptable "form of writing", but it was "not a good way of writing history.... The historian... should not write biography." 15 As David Nasaw put it in his introduction to a 2009 roundtable on Historians and Biography in the American Historical Review, historians have long considered biography a "lesser form of history" incapable of providing the "kind of analytically sophisticated interpretation of the past that academics have long expected." 16 Danish historian Birgitte Possing has described how the popular success of her biography of the important female politician Natalie Zahle provoked the man who had chaired the committee that had approved it as a dissertation to publicly question its academic relevance, a critique that prompted a lively and extended public debate in Denmark". ${ }^{17}$ Of course, opinions such as these were never unanimous and many fine historians did write biographies. E. P. Thompson, one

\footnotetext{
9 Emmanuel Leroy Ladurie, Le territoire de l'historien, v. 1 (Paris, 1973).

10 Jacques Le Goff, "Les mentalités ; une histoire ambiguë", in Le Goff et Nora (dir.), Faire de l'histoire, t. III (Paris 1974).

11 Ferro, Marc. "La biographie, cette handicapée de 1'histoire", Le Magazine littéraire (avril 1989), p. 85-88.

12 Pierre Bourdieu, "L'illusion biographique", Actes de la recherche en sciences sociales, 1986, p. 69-72.

13 Henry James, The Aspern Papers (London, 1888), p. 352.

14 Geoff Eley, A Crooked Line. From Cultural History to the History of Society, (Ann Arbor, 2005)

15 Geoffrey Elton, The Practice of History (London, 1967), p. 135.

16 David Nasaw, "Introduction", American Historical Review, 2009, p. 573.

17 Birgitte Possing, Understanding Biography (Odense, 2016), p. 1-2.
} 
of my own personal patron saints of social history, began his career with a biography of William Morris. ${ }^{18}$

The suspicion of biography endures. In 2011, Jonathan Steinberg, the author of a marvelous biography of Bismarck, could ask "Is biography proper history?" on his publisher's blog. His answer was a qualified yes: "if it asks the kind of questions which an academic historian ca define and offers evidence to support the answer". ${ }^{19}$ As recently as 2014, Daniel Snowman asked a similar question in the popular UK history magazine History Today: "Can biography ever be a serious contribution to history?". ${ }^{20}$

For their part, many people who write biographies see themselves as a guild apart from historians and don't seem to care much about what they think about their craft. This too goes back a long way: Plutarch made no excuses for writing lives rather than histories. The latter, after all, privileged mere facts over character, which is what really mattered. ${ }^{21}$ Today, "biographer" is a professional description for many and there are separate journals, such as the Journal of Historical Biography, separate organizations, such as Biographers' International Organization, which describes itself as "the world's only literary organization devoted to biographers and biography" and awards the Plutarch: "the world's only literary award given to biography by biographers". ${ }^{22}$ There are dedicated centres at a number of universities, including Groenigen in the Netherlands, CUNY and the University of Hawaii in the United States, Barcelona in Spain, and the Australian National University. It is not yet quite a discipline of its own, although there advocates of one called Biography Studies, and the Biography Society describes itself as being "devoted to biography as an object and/or a method of research, with a view to answering the current demand for a theorization of biography as an emerging field, at a crossroads between several disciplines in the humanities". ${ }^{23}$

$$
* * *
$$

During the last twenty years or so, however, the humanities and the social sciences have experienced what has been called a "biographical turn". ${ }^{24}$ History has

\footnotetext{
${ }^{18}$ E. P. Thompson, William Morris: Romantic to Revolutionary (London, 1955).

19Jonathan Steinberg, "Is Biography Proper History", OUPblog, <https:// blog.oup.com/2011/02/biography/>.

${ }^{20}$ Daniel Snowman, "Historical Biography", History Today, v. 64, n. 11, Nov. 2014, <https:/www.historytoday.com/daniel-snowman/historicalbiography>.

21 Nigel Hamilton, "Revisionist Biography Today", Reflections on Biography, 2 September, 2016. <http://biographysociety.org/tag/nigelhamilton/>.

$22<$ http://biographersinternational.org/>; <http://biographersinternational. org/the-plutarch-award/>. Emphasis in original.

$23<$ http://biographysociety.org/about/>.

24 Chamberlaine, Prue, Bornat, Joanna and Wengraf, Tom, eds, The Turn to Biographical Methods in the Social Sciences (London, Verso, 2000).
}

not been exempt and, as Barbara Caine puts it, biography has come "to occupy more of th[e] center ground" of the discipline. ${ }^{25}$ Jo Burr Margadant calls it a "resurrection". ${ }^{26}$ Indeed, historians' attitudes towards biography have changed so significantly that many who formerly rejected it now actively embrace the genre.

I see four reasons for this change. Three of these are specific to the discipline of history. The first is the influence of microhistory as practiced by Carlo Ginzburg, Giovanni Levi and Natalie Zemon Davis, among others, which demonstrated that the story of an individual life, even the most obscure, can both illuminate the past and allow serious historians to reach a wider audience. ${ }^{27}$ The second, ironically, has been the interest in new historical subjects prompted by fields such as labour history, social history, women's history and the histories of racial and ethnic minorities. Initially antagonistic to biography, historians working in these fields have come to see that "[a]s questions about the importance of gender, race and class come to the fore, so too has the recognition that the detailed analysis of individual or collective lives offers one of the best ways to explore them". ${ }^{28}$ Or, as Birgitte Possing puts it, biography can serve as an "element of democratization in a globalized community giving increasing numbers of individuals a place in history, a visibility and a contemporary response". ${ }^{29}$ She cites the example of the distinguished labour and gender historian Alice Kessler-Harris, who went from considering "herself to be an anti-biographer" to writing a biography of the $20^{\text {th }}$-century US female writer Lillian Hellman. ${ }^{30}$ Third, with the realization that people's lives were not always constrained by political borders, the individual life has also become an important way of exploring the vital new fields of transnational, global, and world history as Linda Colley, Martha Hodes, and Maya Jasanoff, among others, have done. ${ }^{31}$

These developments took place against the backdrop of a more general, fourth factor: the collapse of the Soviet Union and consequent crisis of Marxism as an intellectual

\footnotetext{
${ }^{25}$ Barbara Caine, Biography and History (London, 2010), p. 1.

${ }^{26}$ Jo Burr Margadant, The New Biography. Performing Feminity in Nineteenth-Century France (Berkeley, 2000), p. 1.

${ }^{27}$ Carlo Ginzburg, The Cheese and the Worms (Baltimore, Johns Hopkins University Press, 1980); Giovanni Levi, Inheriting Power (Chicago, 1988); Natalie Zemon Davis, The Return of Martin Guerre (Cambridge, Harvard University Press, 1984).

${ }^{28}$ Caine, Biography and History, p. 3.

29 Birgitte Possing, For a fine example of a gender-conscious approach to biography see Biography, Gender and History: Nordic Perspectives (Turku, 2017).

${ }^{30}$ Possing, Understanding Biography, p. 34. See Kessler-Harris' comments in American Historical Review, 2009, p. 625-631.

${ }^{31}$ Colley, Linda, The Ordeal of Elizabeth Marsh: a Woman in World History (New York, Pantheon, 2007); Hodes, Martha, The Sea Captain's Wife: A True Story of Love, Race, and War in the Nineteenth Century, (New York, 2006); Jasanoff, Mata, The Dawn Watch. Joseph Conrad in a Global World (New York, 2017).
} 
approach. This coincided with the rise of postmodernism and the "linguistic turn", and together brought a loss of faith in grand narratives and a new interest in subjectivity.

At the same time, biography itself has been changing in ways that make it more appealing to historians. In general, there has been new concern for the ways in which, as Lois Banner put it, "biography interacts with the history of [the subject's] era", has been recognized as a powerful vehicle for understanding the larger processes of society, culture and politics in a past time and place that are the historian's usual subject. ${ }^{32}$ Biography no longer automatically means a straightforward cradle-to-grave narrative of the life of a great man or, much less frequently, woman. There is now a much greater variety of subjects and ways of approaching their lives.

Historians have played a major role in revitalizing biography in this way. Jo Burr Margadant's 2000 collection, The New Biography. Performing Femininity in Nineteenth-Century France, was a landmark here. ${ }^{33}$ The collection analyzed the lives of eight French women "from socially elite backgrounds" who became celebrities at a time when there were few possibilities for transcending the private sphere for the public one in a respectable way. What made these biographies "new", however, was their methodological approach. Rather than seeking to tell "a coherent story about an identifiably unified, though not necessarily unconflicted, individual," these essays examined the subjects' creation of a "feminine self, legible to the public and credible to herself that might also win approval in at least some influential circles". Their real subject, then, is "self-invention". ${ }^{34}$

In writing my biography, I have been particularly influenced by the work of the Spanish historian Isabel Burdiel. In addition to producing a ground-breaking and prize-winning biography of the nineteenthcentury queen, Isabel II, ${ }^{35}$ she has played a key role in helping reorient the genre, at least among historians of Europe. Between 2008 and 2015 she directed the EUfunded European Network on Theory and Practice of Biography (https://www.uv.es/retpb/index-es.html), whose work led to the publication of the collection $L a$

\footnotetext{
32 Lois Banner, "Biography as History", American Historical Review, 2009, p. 585 .

33 Jo Burr Margadant, The New Biography. Performing Feminity in Nineteenth-Century France (Berkeley, 2000). Hers was not the only proposal for a "new biography" in these years. Nigel Hamilton proposed one "by people, on behalf of the people, and about individual people, produced across a broad spectrum of popular new media", that Hilary Spurling characterized as "a blogger's charter". <https://www. theguardian.com/books/2007/may/20/biography.features $>$. The phrase "new biography" was first used by Virginia Woolf in her article of that name first published in the New York Herald-Tribune on October 20, 1927.

34 Margadant, New Biography, p. 1-7.

35 Isabel Burdiel, Isabel II, (Madrid, 2011)
}

historia biográfica en Europa, which she edited with Roy Foster. ${ }^{36}$

One result has been the development of an approach that French historian Sabine Loriga calls biographical history: "biografías guiadas por problemas históricos sustanciales [which overcome] "la disyuntiva entre excepcionalidad y representatividad para plantear el problema en términos de qué puede aportar el análisis de una trayectoria individual al major conocimiento del pasado, a su carácter plural y abierto". It is a method, in which "importa menos el quien que el como". It also interrogates the conception of greatness which underlays the selection of so many biographical subjects: "es la constitución narrativa del yo como 'personaje', en medio de un coro de voces que pugnan por imponer sus diversas narrativas posibles." ${ }^{37}$ A wonderful example is Lucy Riall's study of Garibaldi, in which his life is less important than understanding how he became "one of the most popular and enduring political heroes of the 19th-century political world... how he became so famous... what message his fame was meant to convey and to whom...the political or cultural import of Garibaldi's celebrity". The result is the exploration of a "sophisticated propaganda exercise" in which Giuseppi Mazzini played a key role, but so did Garibaldi himself. Riall works through a vast range of sources, including new types of publishing products that were emerging at the time, what she calls the "more democratic world of 'low' literature enjoyed by both men and women" and which made possible "the recasting of political struggles as popular entertainment". ${ }^{38}$

That said, there is one way in which biography appears not to have changed that much: It remains, in Possing's phrase, "a male arena". An international she led in 2001 found that 92 per cent of the biographies reviewed in the United States and Europe were about men and 96 per cent were written by men. And a smaller, follow-up found that a decade later, the big picture had "not changed significantly... the majority of biographies still dealt with the men they have always dealt with, these being statesmen and politicians, intellectuals, kings and emperors". 39

\footnotetext{
36 See also her important essay, "Historia política y biografía: más allá de las fronteras", Ayer 93 (2014), p. 47-83.

37 Burdiel, "Historia política y biografía", p. 65.

${ }^{38}$ Lucy Riall, Garibaldi: Invention of a Hero (New Haven, 2007). For another example of this approach see Cazorla-Sánchez, Antonio, Franco: The Biography of the Myth (London, 2016).

39 Possing, Understanding Biography, p. 37-50. An analysis "of 614 works of popular history from 80 houses, which either published books we defined as trade history or landed books we defined as trade history on the New York Times Combined Print \& E-Book Nonfiction best-seller list in 2015popular history books" published in the United States in Slate in January 2016 found that "[b]iographies represented 21 percent of the total number of books published. Their subjects were 71.7 percen male, with the list dominated by big names like Richard Nixon, Winston Churchill, and Napoleon Bonaparte. While some of the biographies of
} 
The new appreciation for biography has included the emergence of a number of what I call unexpected biographers. Ian Kershaw, the author of what may well stand as the definitive biography of Adolf Hitler, began the first volume by confessing that "[b]iography ... never figured in my intellectual plans as something I would want to write". ${ }^{40}$ Other historians have moved from actively rejecting or condemning the genre to practising it. For example, by 1996 Jacques Le Goff, who twenty years earlier had advocated mentalités, was calling biography a "privileged observatory" and writing biographies himself. ${ }^{41}$ Danish historian Hans Kirchoff went from describing biography as "an outdated, at best harmless, genre" in 1978 to publishing, in 2013, a biography of G.F. Duckwitz, the German diplomat who tipped off Danish Jews about their upcoming deportation. ${ }^{42}$ Introducing a special issue of the Journal of the Canadian Historical Association, "The Biographical (ReTurn)", in 2010 Adele Perry and Brian Lewis spoke for many as they described their journey from social history and gender history to biography and is worth quoting at length:

We were both schooled in the new social historical tradition, that grand project arising in the sixties and holding sway for a quarter of a century or more. in trying to write history from below, in moving beyond the top-down decision-making of Great Men, the new social historians sought to uncover the experiences and impact of ordinary people. in deploying statistical and economic data to capture the economic and social fortunes of people who had left few other traces, these historians emphasized collectivities over individuals, marching classes, ethnicities, and genders up and down the pages of their texts. Biographies seemed old fashioned-retaining their appeal among nonacademic writers and to a popular audience, to be sure, but not something able to capture history from below, the longue durée, or the shifting fortunes of ordinary people in a changing world.

The cultural and linguistic turns of the eighties, the rise of poststructuralist and postmodernist analysis and the claiming of a place at the academic table by a new generation of feminist and racially, ethnically and

men were written by women (13 percent), female authors were far more likely than male writers to write biographies about women. Sixty-nine percent of female biography authors wrote about female subjects, and there was a huge gap between this number and the 6 percent of male biography authors who wrote about women. They were struck by the "American fascination with the executive branch was correct, though: of the best-selling books, 21.1 percent were about presidents... Lincoln was king;" one wonders hiow that will change in the age of Donald Trump. Andrew Kahn and Rebecca Onion, "Is History Written About Men, by Men?", <http://www.slate.com/articles/news_and_politics/ history/2016/01/popular_history_why_are_so_many_history_books about men by men.htmi $>$.

40 Ian Kershaw, Hitler 1889-1936: Hubris (London, 1998).

41 Jacques Le Goff, Saint Louis (Paris, 1996); Saint Francis of Assisi (London, 2003)

42 Possing, Understanding Biography, p. 43. sexually diverse scholars all helped to challenge the grand, teleological narratives. With a renewed interest in the individual and in agency, the contextualized biography as an entry-point to a study of a broader world (and psychoanalysis as a means of exploring the interior self) gained a new lease on life and a greater scholarly credibility. ${ }^{43}$

The trajectory Perry and Lewis describe is very much like my own and I want to conclude with a few words about my study of Espartero and how it fits into the evolution of biography I have been describing.

I was first drawn to Espartero many years ago, attracted by the incredible arc of a life which resembles that of a character created by Stendhal or Gabriel García Márquez. Born into obscurity in a rural backwater of central Spain in the waning years of Spain's Old Regime, he had fought against both Napoleon (1808-1814) and Simón Bolívar and other Latin American independence leaders (1815-1824); won a seven-year civil war, the Carlist War of 1833-1840; served as Regent for the child queen Isabella II (1841-1843), spent years in exile in England (1843-1848); governed as Prime Minister (1854-1856); received multiple noble titles, including that of Prince, normally reserved for members of the royal family. In 1870, when Spain was in the midst of searching for a new monarch after the revolution that had chased Isabel II from the throne, he was even a popular candidate to become king.

Espartero's is also a life that lends itself particularly well to biographical history, casting light on broad aspects of Spain's modern history and contributing to the emerging, more sophisticated understanding of its nineteenth century. ${ }^{44}$ One example: political culture and national identity.

The extent to which there was a shared national identity and where it came from have been the major question in historiography of $19^{\text {th }}$-century Spain. The long-standing concern with the supposed deficiencies of the Spanish state and the belief that it had produced an inadequate nationalization, especially when compared to an idealized French model, has more recently given way to a focus on culture and society and on non-state, nonelite, and regional or local agents of nationalization. ${ }^{45}$

\footnotetext{
43 Perry, A. \& Lewis, B. (2010). Introductory Remarks: Special Issue on "The Biographical (Re)Turn". Journal of the Canadian Historical Association, v. 21, n. 2, p. 3-4. doi:10.7202/1003083ar

44 Burdiel, "Historia política y biografía", p. 61.

45 Francisco Javier Corcuera Atienza, "Nacionalismo y clases en la España de la Restauración", Estudios de Historia Social, 28-29, 1984, p. 249-82; Borja de Riquer i Permanyer, "La débil nacionalización española del siglo XIX", Historia Social, 20 (1994), p. 97-114; José Álvarez Junco, Mater dolorosa. La idea de España en el siglo XIX, Madrid, Taurus, 2001; Xosé Manoel Núñez Seixas, "The Region as the Essence of the Fatherland", European History Quarterly, 31/4, 2001, p. 483-518; Ferrán Archilés i Cardona, "Hacer región es hacer patria". La región en el imaginario de la nación española de la Restauración”, Ayer, 64
} 
This new historiography has produced a very different picture, one in which "the chronology of Spanish nation building has changed substantially. The nation now appeared as a catalyst of popular affective and mobilizing loyalty earlier than was thought". Espartero was at the very centre of such mobilization, of what the nation "mean[t] to ordinary people" who, through their autonomous activity, could "construe a national identity out of elements that are not always scooped out to them by the elite... [and] fashion their own national heroes and narratives". ${ }^{46}$

Burdiel's "coro de voces" is crucial here. In Espartero's case, it consists of the many thousands of ordinary people all over Spain who admired, even revered, the man they saw as the unyielding champion of liberty and, especially, the bringer of peace after a long and brutal civil war, "una guerra frátricida de siete años" as so many of them said. It was these people and the entrepreneurs who catered to them by producing estampas, aleluyas, and affordable images and books, who through decades and across generations, often through oral tradition and even naming their sons Baldomero, kept alive what I call the cult of Espartero, a cult to which only those to Napoleon and Garibaldi can compare, long after the political elites had written him off. It was this collective voice, composed of large numbers of individual ones, the vast majority of which were anonymous or not even heard publicly, but expressed themselves in the stories they passed to their children by word of mouth and the thousands of letters and poems they sent to Espartero, that made him Spain's first political celebrity and real public figure, as well as the incarnation of public morality and of the liberal, and even the democratic, nation. ${ }^{47}$

(2006), p. 121-147; Manuel Santirso, España en la Europa liberal (18301870), Barcelona, Ariel, 2008; Romeo, María Cruz: “ ¿Y estos en medio de la nación soberana son por ventura esclavos? Liberalismo, nación y pueblo", Alcores. Revista de Historia Contemporánea, 7 (2009), p. 13-37, "La tradición progresista: historia revolucionaria, historia nacional", en Suárez Cortina, ed., La redención del pueblo: la cultura progresista en la España liberal, Santander, Universidad de Cantabria-Sociedad Menéndez Pelayo, 2006, p. 81-113; Lario, Ángeles: "La monarquía de Isabel II y el liberalismo post-revolucionario. Una necesaria renovación historiográfica", Ayer, 56 (2004), p. 271-282; Fernando Molina, ed., "La nova historiografia del nacionalisme a Espanya", special issue of Rúbrica contemporánea, 6/11, 2017.

46 Fernando Molina and Niguel Cabo Villaverde, "An Inconvenient Nation: Nation Building and National identity in Modern Spain. The Historiographical Debate", in Marten Van Ginderachter and Marnic Beyen, eds., Nationhood from Below. Europe in the Long Nineteenth Century, (London, Palgrave, 2012), p. 66, 8, 14; Javier Moreno-Luzón and Xosé M. Núñez Seixas, eds, Metaphors of Spain: representations of Spanish national identity in the twentieth century (New York, 2017).

47 See my article, "Being - and Staying - Famous in $19^{\text {th }}$-century Spain: Baldomero Espartero and the Birth of Political Celebrity", Historia y Politica, (Julio-Diciembre 2015), p. 211-37. On Espartero in the politicxal culture of Cataluña, see my article "Quan Catalunya celebrava Espartero, 1856-1868”, Recerques, 73 (2017), p. 105-131. My work on Espartero also casts light on questions of gender relations in Spain's emerging liberal polity and society. See my article "Baldomero and Jacinta: Scenes from a Nineteenth-Century Spanish Marriage, 1827-1878”, Journal of Modern History (December 2017), p. 749-771.

\section{References}

ÁLVAREZ JUNCO, J. Mater dolorosa. La idea de España en el siglo XIX. Madrid, Taurus, 2001.

ARCHILÉS I CARDONA, F. Hacer región es hacer patria. La región en el imaginario de la nación española de la Restauración. Ayer, v. 64, p. 121-147, 2006.

BANNER, L. Biography as History. In: American Historical Review, v. 114, n. 3, p. 585, 2009.

BOURDIEU, P. L'illusion biographique. Actes de la recherche en sciences sociales. 1986. p. 69-72.

BRAUDEL, F. Histoire et Sciences Sociales: La longue durée. In: Réseaux-Communication-Technologie-Société, v. 5, n. 27, p. 7-37, 1987

BURDIEL, I. Historia política y biografía: más allá de las fronteras. In: Ayer, v. 93, p. 47-83, 2014.

BURDIEL, I. Isabel II. Madrid: Taurus, 2011.

CAINE, B. Biography and History. London: MacMillan, 2010. p. 1.

CAZORLA-SÁNCHEZ, A. Franco: The Biography of the Myth. London: Routledge, 2016.

CHAMBERLAINE, P.; BORNAT, J.; WENGRAF, T. (eds.). The Turn to Biographical Methods in the Social Sciences. London: Verso, 2000.

COLLEY, L. The Ordeal of Elizabeth Marsh: a Woman in World History. New York: Pantheon, 2007.

CORCUERA ATIENZA, F. J. Nacionalismo y clases en la España de la Restauración. In: Estudios de Historia Social, n. 28-29, p. 249-282, 1984.

DAVIS, N. Z. The Return of Martin Guerre. Cambridge: Harvard University Press, 1984.

ELEY, G. A Crooked Line. From Cultural History to the History of Society. Ann Arbor: University of Michigan Press, 2005.

ELTON, G. The Practice of History. London: Fontana, 1967. p. 135 .

FERRO, M. La biographie, cette handicapée de l'histoire. In: Le Magazine littéraire, n. 264, p. 858, avril 1989.

GINZBURG, C. The Cheese and the Worms. Baltimore: Johns Hopkins University Press, 1980.

HABERMAN, A.; SHUBERT, A. The West and the World: Contacts, Conflicts, Connections. Toronto: Gage, 2002.

HAMILTON, N. Oh come on, it's time you got a life. In: The Guardian, 20 May 2007. <https://www.theguardian.com/ books/2007/may/20/biography.features>.

HAMILTON, N. Revisionist Biography Today. Reflections on Biography, 2016, Sept. 2 <http://biographysociety.org/tag/ nigel-hamilton/>.

HODES, M. The Sea Captain's Wife: A True Story of Love, Race, and War in the Nineteenth Century. New York: Norton, 2006.

HOFFMANN, M. He Built Roads. He Oversaw Mines. He Shrank the Deficit. He Was Johann Wolfgang von Goethe. In: New York Times, 2017, June 16. <https://www.nytimes. com/2017/06/16/books/review/goethe-biography-rudigersafranski.html>. 
JAMES, H. The Aspern Papers. London: MacMillan, 1888. p. 352.

JASANOFF, M. The Dawn Watch. Joseph Conrad in a Global World. New York: Penguin, 2017.

KERSHAW, I. Hitler 1889-1936: Hubris. London: Allen Lane, 1998.

KESSLER-HARRIS. Why biography. In: American Historical Review, v. 114 n. 3, p. 625-631, 2009.

LADURIE, E. L. Le territoire de l'historien. Paris: Gallimard, 1973. v. 1.

LARIO, Ángeles: La monarquía de Isabel II y el liberalismo post-revolucionario. Una necesaria renovación historiográfica. Ayer, 56 (2004), p. 271-282.

LE GOFF, J. Saint Francis of Assisi. London: Routledge, 2003.

LE GOFF, J. Les mentalités; une histoire ambiguë. In: LE GOFF-NORA(Ed.). Faire de l'histoire. Paris: Routledge, 1974. t. III.

LE GOFF, J. Saint Louis. Paris: Routledge, 1996.

LEVI, G. Inheriting Power. Chicago: University of Chicago Press, 1988.

MacLEnNAN, H. Two Solitudes. Toronto: MacMillan of Canada, 1945.

MARGADANT, J. B. The New Biography. Performing Feminity in Nineteenth-Century France. Berkeley: University of California Press, 2000.

MOLINA, F. (Ed.). La nova historiografia del nacionalisme a Espanya. Rúbrica contemporánea, v. 6, n. 11 (sp. issue), 2017.

MOLINA, F.; VILLAVERDE, N. C. An Inconvenient Nation: Nation Building and National identity in Modern Spain. The Historiographical Debate. In: VAN GINDERACHTER, M.; BEYEN, M. (Ed.). Nationhood from Below. Europe in the Long Nineteenth Century. London: Palgrave, 2012.

MORENO-LUZÓN, J.; NÚÑEZ SEIXAS, X. M. (Ed.). Metaphors of Spain: representations of Spanish national identity in the twentieth century. New York: Berghahn, 2017.

NASAW, D. Introduction. In: American Historical Review, v. 114, n. 3, p. $573,2009$.

NÚÑEZ SEIXAS, X. M. The Region as the Essence of the Fatherland. In: European History Quarterly, v. 31, n. 4, p. 483-518, 2001.

PERRY, A.; LEWIS, B. Introductory Remarks: Special Issue on "The Biographical (Re)Turn". Journal of the Canadian Historical Association, v. 21, n. 2, p. 3-4, 2010. <http://dx.doi. org/10.7202/1003083ar>.

POSSING, B. Biography, Gender and History: Nordic Perspectives. Turku: University of Turku Press, 2017.

POSSING, B. Understanding biography. Odense: University Press of Southern Denmark, 2016. p. 1-2; p. 37-50. <http:// www.slate.com/articles/news_and_politics/history/2016/01/ popular_history_why_are_so_many_history_books_about men_by_men.html>.

RIALL, L. Garibaldi: Invention of a Hero. New Haven: Yale University Press, 2007.
RIQUER, I.; PERMANYER, B. La débil nacionalización española del siglo XIX. Historia Social, v. 20, p. 97-114, 1994.

ROMEO, María Cruz. ¿Y estos en medio de la nación soberana son por ventura esclavos? Liberalismo, nación y pueblo. Alcores - Revista de Historia Contemporánea, v. 7, p. 13-37, 2009.

ROMEO, María Cruz. La tradición progresista: historia revolucionaria, historia nacional. In: CORTINA, S. (ed.). La redención del pueblo: la cultura progresista en la España liberal. Santander: Universidad de Cantabria-Sociedad Menéndez Pelayo, 2006. p. 81-113.

SANTIRSO, M. España en la Europa liberal (1830-1870). Barcelona: Ariel, 2008.

SHUBERT, A. A las cinco de la tarde: una historia social del toreo. Madrid: Turner, 2002.

SHUBERT, A. Baldomero and Jacinta: Scenes from a Nineteenth- Century Spanish Marriage, 1827-1878. In: Journal of Modern History, v. 89 n. 4, p. 749-771, Dec. 2017.

SHUBERT, A. Being - and Staying - Famous in $19^{\text {th }}$-century Spain: Baldomero Espartero and the Birth of Political Celebrity. In: Historia y Política, n. 34, p. 211-237, jul.-dic. 2015.

SHUBERT, A. Espartero. El Pacificador. Barcelona: Galaxia Gutenberg, 2018.

SHUBERT, A. Hacia la revolución: orígenes sociales del movimiento obrero en Asturias, 1860-1934. Barcelona: Grupo Grijalbo, 1984.

SHUBERT, A. Historia social de España (1800-1990). Madrid: Nerea, 2000.

SHUBERT, A. Quan Catalunya celebrava Espartero, 18561868. In: Recerques, v. 73, p. 105-131, 2017.

SNOWMAN, D. Historical Biography. History Today, v. 64, n. 11, Nov. 2014. <https://www.historytoday.com/danielsnowman/historical-biography>.

STEINBERG, J. Is Biography Proper History. OUPblog, $<$ https://blog.oup.com/2011/02/biography/>.

THOMPSON, E. P. The making of the english working class. London: Victor Gollancz, 1963.

THOMPSON, E. P. The Peculiarities of the English. In: The Socialist Register. London: Victor Gollancz, 1965. p. 311-362.

THOMPSON, E. P. William Morris: Romantic to Revolutionary. New York: Pantheon, 1977 (1. ed.: London, 1955).

WOOLF, V. The New Biography. In: New York Herald-Tribune, 1927, Oct. 20.

\section{Sites:}

$<$ http://biographersinternational.org/>.

$<$ http://biographers international.org/the-plutarch-award/>.

$<$ http://biographysociety.org/about/>.

Recebido: 07/02/2018

Aprovado: 07/03/2018

Contato:

Adrian Shubert<adriansh@yorku.com> 